\title{
Biodiversity of weed community in maize in the Cieszyńskie Foothills
}

\author{
Bioróżnorodność zbiorowisk chwastów w uprawie kukurydzy \\ na Pogórzu Cieszyńskim
}

\author{
Eugeniusz Chwastek ${ }^{1}$, Robert Idziak ${ }^{2 *}$, Hubert Waligóra ${ }^{2}$
}

\begin{abstract}
Summary
Studies carried out in the years 2012-2018 on Cieszyńskie Foothills fields (26 localities in 7 boroughs) with maize in order to determine weed species and segetal association. Phytosociological relevés were made using Braun-Blanquet method with recommended parameters and coefficients (number of records, abundance, covering). 124 weed species were observed in maize, with a predominance of species from classes not associated with segetal association. Species from Stellerieta mediae class represented $44 \%$ of all species. Segetal species occurred with taxa from other phytosociological classes (55\%) which were dominated by species belonging to meadow communities from Molinio-Arrhenatheretea and Artemisietea vulgaris class, presenting ruderal species and a few species from other classes, including Agropyro-intermedio repentis, Bidentetea tripartiti, Isoëto-Nanojuncetea, Querco-fagetea, Rhamno-Prunetea, and Trifolio-Geranietea sanguinei.
\end{abstract}

Key words: weeds, maize, invasive plants, anthropophytes

\section{Streszczenie}

Badania przeprowadzono w latach 2012-2018 na polach Pogórza Cieszyńskiego (26 miejscowości w 7 gminach) obsianych kukurydzą w celu określenia gatunków chwastów oraz zespołów segetalnych. Zdjęcia fitosocjologiczne wykonano stosując metodę Brauna-Blanqueta, z zastosowaniem zalecanych parametrów i współczynników (stopień występowania, ilościowość, pokrycie). W kukurydzy stwierdzono występowanie 124 gatunków chwastów z przewagą gatunków z klas niezwiązanych z zespołami segetalnymi. Gatunki klasy Stellerieta mediae stanowiły $44 \%$ ogółu gatunków chwastów. Gatunkom segetalnym towarzyszyły taksony innych klas fitosocjologicznych (55\%), wśród których dominowały gatunki zbiorowisk łąkowych klasy Molinio-Arrhenatheretea i Artemisietea vulgaris, prezentujące gatunki ruderalne oraz nieliczne gatunki innych klas, w tym Agropyron-intermedio repentis, Bidentetea tripartiti, Isoëto-Nanojuncetea, Quercofagetea, Rhamno-Prunetea i Trifolio-Geranietea sanguinei.

Słowa kluczowe: chwasty, kukurydza, gatunki inwazyjne, antropofity

\author{
III Liceum Ogólnokształcące im. Stanisława Wyspiańskiego \\ Elfów 62, 43-100 Tychy \\ ${ }^{2}$ Uniwersytet Przyrodniczy w Poznaniu \\ Dojazd 11, 60-632 Poznań \\ *corresponding author: robert.idziak@up.poznan.pl \\ ORCID: 0000-0002-1621-9184
}




\section{Wstęp / Introduction}

Kukurydza jest gatunkiem charakteryzującym się niską konkurencyjnością w stosunku do chwastów (Waligóra i wsp. 2008), a straty plonu wynikające z ich obecności, w zależności od poziomu ochrony mogą wynosić od kilkunastu do nawet ponad 80\% (Imoloame i Omolaiye 2017). Według Matuszkiewicza (2001) roślinom uprawnym towarzyszą zazwyczaj swoiste dla nich zbiorowiska chwastów. Skład zbiorowiska chwastów jest uzależniony od szeregu czynników, takich jak region geograficzny i klimat, a także rodzaj uprawianej rośliny, przedplon, właściwości i typ gleby (Fried i wsp. 2008), system uprawy roli oraz ilość i rozmieszczenie nasion chwastów w profilu glebowym (Piskier i Sekutowski 2013).

Pogórze Cieszyńskie w zachodniej części Pogórza Śląskiego charakteryzuje się specyfiką dotyczącą zarówno warunków klimatycznych, jak i glebowych. Są to główne czynniki, które pozwalają na uprawę kukurydzy w tym regionie. Ważny jest również dobór odmian oraz odpowiednia technologia uprawy pozwalająca na uprawę kukurydzy w warunkach typowych dla pasma pogórzy. Kukurydza zwyczajna (Zea mays L.) na Pogórzu Cieszyńskim nie była zbyt entuzjastycznie przyjmowana, szczególnie w latach 60. ubiegłego wieku, kiedy możliwa była uprawa z przeznaczeniem na zielonkę lub kiszonkę. Wynikało to głównie z braku odmian dostosowanych do warunków klimatycznych i glebowych Pogórza Cieszyńskiego. Aktualnie kukurydza jest ważną rośliną uprawną na Pogórzu Cieszyńskim, uprawianą zarówno na kiszonkę, jak i na ziarno. Zwiększająca się powierzchnia upraw, jak i częstsze pojawianie się tej rośliny na tym samym polu, sprzyja występowaniu chwastów towarzyszącym jej uprawom (Kierzek i wsp. 2011).

Problem zachwaszczenia i wpływ chwastów na wzrost i rozwój oraz plonowanie kukurydzy, w literaturze omawiany jest bardzo szeroko (Wesołowski i Woźniak 1998; Dubas i wsp. 2002; Majchrzak i wsp. 2003; Rychcik i wsp. 2003; Blecharczyk i wsp. 2004; Rola i wsp. 2005; Gołębiowska 2006, 2007; Pudełko i wsp. 2006; Rychcik 2006; Sowiński 2006; Głowacka 2007; Majchrzak i Skrzypczak 2007; Szulc i Dubas 2008). Jednak powyższe badania nie uwzględniały rejonu Pogórza Cieszyńskiego.

Celem badań była ocena składu gatunkowego zbiorowisk chwastów w łanie kukurydzy uprawianej w warunkach Pogórza Cieszyńskiego.

\section{Materiały i metody / Materials and methods}

Badania dotyczące zachwaszczenia pól uprawnych obsianych kukurydzą, przeprowadzone w latach 2012-2018, opierały się na eksploracji upraw rolniczych Pogórza Cieszyńskiego i określeniu występujących tam gatunków chwastów oraz ustaleniu zespołów segetalnych (Pawłowski 1972). Typy, podtypy gleb i kompleksy glebowe określano na podstawie mapy numerycznej w skali 1 : 75 000, opracowanej w Instytucie Uprawy Nawożenia i Gleboznawstwa - Państwowym Instytucie Badawczym, na podstawie analogowej mapy glebowo-rolniczej w skali $1: 25$ 000. Nazewnictwo roślin przyjęto na podstawie „Flovering Plants and Pteridiophytes of Poland. A Checklist" (Mirek i wsp. 2002). Zebrany materiał poddano analizie, skupiając się na gatunkach prezentujących poszczególne grupy antropofitów (Tokarska-Guzik i wsp. 2012). W opracowaniu skupiono się na archeofitach i kenofitach.

Zdjęcia fitosocjologiczne o powierzchni $100 \mathrm{~m}^{2}$ wykonano stosując tradycyjną metodę Brauna-Blanqueta, z zastosowaniem zalecanych parametrów i współczynników (stopień występowania, ilościowość, pokrycie). W okresie badań na Pogórzu Cieszyńskim wykonano 89 zdjęć fitosocjologicznych. Ilościowość chwastów podano w oparciu o skalę Braun-Blanqueta (Woźniak i Soroka 2015), przyjmując: 5 - liczba osobników dowolna, pokrycie powierzchni zdjęcia powyżej 75\%; 4 - liczba osobników dowolna, pokrycie $50-75 \% ; 3$ - liczba osobników dowolna, pokrycie 25-50\%; 2 - liczba osobników duża, pokrycie 5-25\%; 1 - liczba osobników 5-50, pokrycie $>5 \%$; + - liczba osobników niewielka ( 2 do 5), pokrycie $<5 \%$; r - liczba osobników bardzo mała (1 okaz). Stałość fitosocjologiczną (klasa stałości) zbiorowiska roślinnego wyrażono również według skali Braun-Blanqueta, gdzie przyjęto, że: V - gatunki pojawiające się stale i często (występujące w 80,1-100\% badanych lat), IV - gatunki częste (w 60,1-80\%), III - średnio częste $(40,1-60 \%)$, II - niezbyt częste $(20,1-40 \%)$ oraz I - sporadyczne lub rzadkie (0,1-20\%) (Wanic i wsp. 2005). Współczynnik pokrycia obliczono posługując się wzorem (Gołębiowska i wsp. 2015):

$$
\mathrm{Wp}=(\mathrm{Pg} / \mathrm{Lz}) \times 100
$$

gdzie:

Wp - współczynnik pokrycia,

Pg - suma średnich procentów przeciętnego pokrycia gatunku na danej powierzchni we wszystkich zdjęciach fitosocjologicznych,

Lz - ogólna liczba zdjęć.

Podziału gatunków na grupy geograficzno-historyczne dokonano wykorzystując opracowania Celki (2004) i Chmiela (2006).

Badania prowadzone były w 26 miejscowościach położonych w siedmiu gminach Pogórza Cieszyńskiego: Brenna, Cieszyn, Dębowiec, Goleszów, Hażlach, Skoczów, Ustroń. Tabela 1. zawiera dane określające lokalizacje kwadratów ATPOL o boku $2 \times 2 \mathrm{~km}$. W celu przybliżenia warunków prowadzenia badań poniżej przedstawiono charakterystyczne cechy klimatyczne rejonu (tab. 2).

Na obszarze, na którym wykonano obserwacje, występują głównie gleby brunatne (właściwe, wyługowane i kwa- 
Tabela 1. Lokalizacja miejscowości objętych badaniami

Table1. Location of the towns covered by the study

\begin{tabular}{|c|c|c|}
\hline Gmina - Boroughs & Miejscowość - Localities & Kwadrat ATPOL - ATPOL square \\
\hline Brenna & Górki Wielkie & DF 9134 \\
\hline \multirow{2}{*}{ Cieszyn } & Cieszyn & DF 9042 \\
\hline & Cieszyn-Krasna & DG 0004 \\
\hline \multirow{7}{*}{ Dębowiec } & Dębowiec & DF 9014 \\
\hline & Gumna & DF 9043, DF 9044 \\
\hline & Iskrzyczyn & DF 9120, DF 9130 \\
\hline & Łączka & DF 9130 \\
\hline & Kostkowice & DF 9034 \\
\hline & Ogrodzona & DF 9044, DG 0100 \\
\hline & Simoradz & DF 9120, DF 9121 \\
\hline \multirow{7}{*}{ Goleszów } & Dzięgielów & DG 0013, DG 0014, DG 0024 \\
\hline & Bażanowice & DG 0004 \\
\hline & Godziszów & DF 9140, DF 9141, DG 0100 \\
\hline & Leszna Górna & DG 0024, DG 0034 \\
\hline & Kisielów & DF 9141 \\
\hline & Kozakowice Dolne & DG 0101 \\
\hline & Puńców & DG 0013, DG 0022, DG 0023 \\
\hline Hażlach & Zamarski & DF 9032, DF 9033, DF 9043 \\
\hline \multirow{6}{*}{ Skoczów } & Bładnice Dolne & DF 9141, DF 9142 \\
\hline & Kowale & DF 9014, DF 9114 \\
\hline & Pierściec & DF 9103 \\
\hline & Pogórze & DF 9123, DF 9124, DF 9130 \\
\hline & Wilamowice & DF 9121 \\
\hline & Wiślica & DF 0112 \\
\hline \multirow{2}{*}{ Ustroń } & Lipowiec & DG 0104 \\
\hline & Ustroń & DG 0112 \\
\hline
\end{tabular}

Tabela 2. Charakterystyczne cechy klimatyczne Dzielnicy Podkarpackiej (Sosna 1997)

Table 2. Characteristic climatic features Subcarpathian Discrict (Sosna 1997)

\begin{tabular}{l|c}
\hline \multicolumn{1}{c|}{ Cecha - Feature } & Wartość - Value \\
\hline Średnia temperatura roczna - Average annual temperature & $7-8^{\circ} \mathrm{C}$ \\
Średnia temperatura lipca - Average July temperature & $17,5-18,5^{\circ} \mathrm{C}$ \\
Liczba dni z przymrozkami - Number of freeze days & do - to 110 \\
Liczba dni mroźnych - Number of frosty days & $30-40$ \\
Liczba dni gorących - Number of hot days & $20-40$ \\
Długość okresu wegetacyjnego - Growing season lenght & do - to 225 dni - days \\
Czas trwania zimy - Duration of winter & $60-70$ dni - days \\
Czas trwania lata - Duration of summer & $70-90$ dni - days \\
Opady - Precipitation & $750-1000 \mathrm{~mm}$ \\
Liczba dni z pokrywą śnieżną - Number of day with snow cover & $55-80$ dni - days \\
\hline
\end{tabular}

śne) oraz rędzinowe (Lazar 1962), o odczynie zbliżonym do lekko kwaśnego, obojętnego lub zasadowego, na których uprawa kukurydzy zarówno na kiszonkę, jak i ziarno może przynosić dobre rezultaty. 
Tabela 3. Struktura zasiewów w rejonie badań

Table 3. Sowing structure in the study area

\begin{tabular}{|c|c|c|c|c|c|c|c|c|}
\hline $\begin{array}{l}\text { Lokalizacja } \\
\text { Location }\end{array}$ & $\begin{array}{c}\text { Pszenica } \\
\text { ozima i jara } \\
\text { Winter and } \\
\text { spring wheat }\end{array}$ & \begin{tabular}{|c|} 
Jęczmień \\
ozimy i jary \\
Winter and \\
spring barley
\end{tabular} & $\begin{array}{c}\text { Owies } \\
\text { Oat }\end{array}$ & $\begin{array}{l}\text { Mieszanki } \\
\text { zbożowe } \\
\text { Cereal } \\
\text { mixtures }\end{array}$ & $\begin{array}{l}\text { Ziemniaki } \\
\text { Potatoes }\end{array}$ & $\begin{array}{c}\text { Buraki } \\
\text { Beet }\end{array}$ & $\begin{array}{c}\text { Rzepak ozimy } \\
\text { Oilseed rape }\end{array}$ & $\begin{array}{c}\text { Kukurydza } \\
\text { Maize }\end{array}$ \\
\hline Brenna & 128 & 56 & 86 & 133 & 85 & - & - & 10 \\
\hline Cieszyn & 190 & 77 & 48 & 62 & 37 & 3 & - & 19 \\
\hline Dębowiec & 606 & 283 & 97 & 166 & 93 & 1 & 78 & 144 \\
\hline Goleszów & 797 & 218 & 97 & 234 & 111 & 14 & 74 & 164 \\
\hline Hażlach & 500 & 243 & 206 & 427 & 170 & 32 & 48 & 167 \\
\hline Skoczów & 587 & 129 & 188 & 193 & 154 & 44 & 5 & 98 \\
\hline Ustroń & 133 & 83 & 67 & 106 & 66 & - & - & 5 \\
\hline Razem - Total & 2941 & 1089 & 789 & 1321 & 716 & 94 & 205 & 607 \\
\hline
\end{tabular}

Tabela 4. Udział użytków rolnych w gminach objętych badaniami

Table 4. Share of farmland in boroughs area embraced in the study

\begin{tabular}{l|c|c}
\hline $\begin{array}{c}\text { Gmina } \\
\text { Borough }\end{array}$ & $\begin{array}{c}\text { Rodzaj gminy } \\
\text { Kind of borough }\end{array}$ & $\begin{array}{c}\text { Udział użytków rolnych [\%] } \\
\text { Share of farmland [\%] }\end{array}$ \\
\hline Brenna & wiejska (charakter pogórski) - rural (hillside) & 30 \\
\hline Cieszyn & miejska - municipal ditrict & 55 \\
\hline Dębowiec & wiejska - rural & 71 \\
\hline Goleszów & wiejska (charakter pogórski) - rural (hillside) & 72 \\
\hline Hażlach & wiejska - rural & 72 \\
\hline Skoczów & miejsko-wiejska - municipal-rural & 63 \\
\hline Ustroń & miejska (charakter pogórski) - municipal district (hillside) & 41 \\
\hline
\end{tabular}

W strukturze zasiewów w badanym rejonie znajdowały się przede wszystkim zboża, w tym kukurydza, a także rośliny okopowe i rzepak (tab. 3). Struktura zasiewów terenu badań wynika z uwarunkowań fizjogeograficznych i administracyjnych, które zestawiono w tabeli 4.

\section{Wyniki i dyskusja / Results and discussion}

Wyniki obserwacji uzyskane na podstawie analizy zdjęć fitosocjologicznych wykazały występowanie 124 gatunków chwastów w uprawie kukurydzy na Pogórzu Cieszyńskim. Gatunki klasy Stellarietea mediae w liczbie 55 gatunków stanowiły 44,4\% ogółu gatunków chwastów. Sobiech i wsp. (2018) wskazują także na obecność w łanie kukurydzy gatunków z klasy Stellarietea mediae, jak również Aperionspicae-venti i innych zaliczanych do gatunków towarzyszących. Gatunkom segetalnym towarzyszyły taksony innych klas fitosocjologicznych (tab. 5). Stanowiły one 55,6\% ogólnej liczby gatunków chwastów odnotowanych w uprawach kukurydzy. Dominowały tu gatunki zbiorowisk łąkowych klasy Molinio-Arrhenatheretea oraz Artemisietea vulgaris - prezentujące gatunki ruderalne, a także nieliczne gatunki innych klas, w tym Agropyro-intermedio repentis, Bidentetea tripartiti, Isoëto-Nanojuncetea, Querco-fagetea, Rhamno-Prunetea, Trifolio-geranietea sanguinei. Uzupełnienie składu gatunkowego stanowiły taksony bez przynależności fitosocjologicznej (tab. 5). Są to między innymi kenofity inwazyjne: Amaranthus retroflexus, Lolium multiflorum oraz zadomowiony archeofit - Sherardia arvensis. W ostatnich latach obserwuje się ponadto występowanie Abutilon theophrasti - zaślazu pospolitego, który osiąga znaczne wartości ilościowości w uprawach kukurydzy.

Analiza gatunków chwastów występujących w uprawach kukurydzy wykazała obecność 54 gatunków antropofitów, z których 44 gatunki przypisane są do klasy Stellarietea mediae (tab. 5, 6). Wśród antropofitów odnotowanych w obrębie klasy Stellarietea mediae przeważały archeofity, które stanowiły 90,6\% ogólnej liczby antropofitów. Wszystkie ar- 
Tabela 5. Gatunki chwastów według przynależności fitosocjologicznej

Table 5. Weed species according to phytosocioligal affiliation

\begin{tabular}{l|c|c}
\hline \multicolumn{1}{c|}{ Klasa - Class } & $\begin{array}{c}\text { Udział - Share } \\
{[\%]}\end{array}$ & Liczba gatunków - Number of species \\
\hline Stellarietea mediae & 44,4 & 55 \\
\hline Artemisietea vulgaris & 9,7 & 12 \\
\hline Molinio-Arrhenatheretea & 20,9 & 15 \\
\hline Pozostałe - Other & 12,0 & 16 \\
\hline Bez przynależności - No affiliation & 13,0 & 124 \\
\hline Razem - Total & 100 & \\
\hline
\end{tabular}

Tabela 6. Charakterystyka antropofitów najczęściej występujących w uprawach kukurydzy na Pogórzu Cieszyńskim

Table 6. Characteristics of anthropophytes most frequently found in maize crops in the Cieszyńskie Foothills

\begin{tabular}{|c|c|c|c|c|c|}
\hline $\begin{array}{l}\text { Gatunek } \\
\text { Species }\end{array}$ & $\begin{array}{l}\text { Liczba } \\
\text { wystapień } \\
\text { No. of } \\
\text { records }\end{array}$ & $\begin{array}{l}\text { Klasa stałości } \\
\text { Constancy } \\
\text { class }\end{array}$ & $\begin{array}{l}\text { Ilościowość } \\
\text { min./max. } \\
\text { Abundance } \\
\text { min./max. }\end{array}$ & $\begin{array}{c}\text { Grupa } \\
\text { geograficzno-historyczna } \\
\text { Geografical-historical } \\
\text { group }\end{array}$ & $\begin{array}{l}\text { Współczynnik pokrycia } \\
\text { Cover coefficient }\end{array}$ \\
\hline 1 & 2 & 3 & 4 & 5 & 6 \\
\hline \multicolumn{6}{|c|}{ Stellarietea mediae } \\
\hline $\begin{array}{l}\text { Aethusa cynapium subsp. } \\
\text { agrestis }\end{array}$ & 37 & III & $(\mathrm{r}-2.3)$ & $\begin{array}{c}\text { archeofit zadomowiony ustępujący } \\
\text { settled archaeophyte receding }\end{array}$ & 100,7 \\
\hline Anagallis arvensis & 31 & II & $(+-2.3)$ & $\begin{array}{l}\text { archeofit zadomowiony } \\
\text { settled archaeophyte }\end{array}$ & 39,7 \\
\hline Apera spica-venti & 5 & I & $(\mathrm{r}-+.2)$ & $\begin{array}{l}\text { archeofit zadomowiony } \\
\text { settled archaeophyte }\end{array}$ & - \\
\hline Atriplex patula & 18 & II & $(r-3.4)$ & $\begin{array}{l}\text { archeofit zadomowiony } \\
\text { settled archaeophyte }\end{array}$ & 105,1 \\
\hline Avena fatua & 15 & I & $(\mathrm{r}-2.3)$ & $\begin{array}{c}\text { archeofit zadomowiony inwazyjny } \\
\text { settled invasive archaeophyte }\end{array}$ & 31,6 \\
\hline Capsella bursa-pastoris & 1 & I & $(\mathrm{r}-+)$ & $\begin{array}{c}\text { archeofit zadomowiony } \\
\text { settled archaeophyte }\end{array}$ & - \\
\hline Echinochloa crus-galli & 72 & $\mathrm{~V}$ & $(r-3.4)$ & $\begin{array}{c}\text { archeofit zadomowiony inwazyjny } \\
\text { settled invasive archaeophyte }\end{array}$ & 489,9 \\
\hline Euphorbia helioscopia & 29 & II & $(\mathrm{r}-1.2)$ & $\begin{array}{l}\text { archeofit zadomowiony } \\
\text { settled archaeophyte }\end{array}$ & 8,0 \\
\hline Fallopia convolvulus & 50 & III & $(\mathrm{r}-2.3)$ & $\begin{array}{l}\text { archeofit zadomowiony } \\
\text { settled archaeophyte }\end{array}$ & 135,6 \\
\hline Fumaria officinalis & 10 & I & $(\mathrm{r}-3.3)$ & $\begin{array}{l}\text { archeofit zadomowiony } \\
\text { settled archaeophyte }\end{array}$ & 79,1 \\
\hline Geranium dissectum & 38 & III & $(\mathrm{r}-3.3)$ & $\begin{array}{l}\text { archeofit zadomowiony } \\
\text { settled archaeophyte }\end{array}$ & 142,5 \\
\hline Kickxia elatine & 14 & I & $(+-2.3)$ & $\begin{array}{c}\text { archeofit zadomowiony ustępujący } \\
\text { settled archaeophyte receding }\end{array}$ & 82,3 \\
\hline Kickxia spuria & 2 & I & (r) & $\begin{array}{c}\text { archeofit zadomowiony ustępujący } \\
\text { settled archaeophyte receding }\end{array}$ & - \\
\hline Lamium purpureum & 11 & II & $(\mathrm{r}-1.2)$ & $\begin{array}{c}\text { archeofit zadomowiony } \\
\text { settled archaeophyte }\end{array}$ & 7,4 \\
\hline Lathyrus tuberosus & 1 & I & $(+.2)$ & $\begin{array}{c}\text { archeofit zadomowiony ustępujący } \\
\text { settled archaeophyte receding }\end{array}$ & - \\
\hline
\end{tabular}


Tabela 6. Charakterystyka antropofitów najczęściej występujących w uprawach kukurydzy na Pogórzu Cieszyńskim - cd. Table 6. Characteristics of anthropophytes most frequently found in maize crops in the Cieszyńskie Foothills - continued

\begin{tabular}{|c|c|c|c|c|c|}
\hline 1 & 2 & 3 & 4 & 5 & 6 \\
\hline $\begin{array}{l}\text { Matricaria maritima subsp. } \\
\text { inodora }\end{array}$ & 12 & I & $(\mathrm{r}-+.2)$ & $\begin{array}{l}\text { archeofit zadomowiony } \\
\text { settled archaeophyte }\end{array}$ & 0,9 \\
\hline Melandrium noctiflorum & 3 & I & $(+)$ & $\begin{array}{l}\text { archeofit zadomowiony ustępujący } \\
\text { settled archaeophyte receding }\end{array}$ & - \\
\hline Myosotis arvensis & 7 & I & $(\mathrm{r}-+)$ & $\begin{array}{l}\text { archeofit zadomowiony } \\
\text { settled archaeophyte }\end{array}$ & - \\
\hline Papaver rhoeas & 4 & I & $(\mathrm{r}-1.2)$ & $\begin{array}{l}\text { archeofit zadomowiony } \\
\text { settled archaeophyte }\end{array}$ & 6 \\
\hline Raphanus raphanistrum & 4 & I & $(\mathrm{r}-+.2)$ & $\begin{array}{l}\text { archeofit zadomowiony } \\
\text { settled archaeophyte }\end{array}$ & - \\
\hline Setaria pumila & 46 & III & $(+-3.4)$ & $\begin{array}{l}\text { archeofit zadomowiony inwazyjny } \\
\text { settled invasive archaeophyte }\end{array}$ & 263,6 \\
\hline Setaria viridis & 3 & I & $(+-1.2)$ & $\begin{array}{l}\text { archeofit zadomowiony inwazyjny } \\
\text { settled invasive archaeophyte }\end{array}$ & 6 \\
\hline Silene gallica & 1 & I & $(+)$ & $\begin{array}{c}\text { archeofit zadomowiony ustępujący } \\
\text { settled archaeophyte receding }\end{array}$ & - \\
\hline Solanum nigrum & 18 & II & $(r-3.3)$ & $\begin{array}{l}\text { archeofit zadomowiony } \\
\text { settled archaeophyte }\end{array}$ & 88,5 \\
\hline Sonchus asper & 10 & I & $(\mathrm{r}-2.3)$ & $\begin{array}{l}\text { archeofit zadomowiony } \\
\text { settled archaeophyte }\end{array}$ & 56,5 \\
\hline Sonchus oleraceus & 1 & I & (r) & $\begin{array}{l}\text { archeofit zadomowiony } \\
\text { settled archaeophyte }\end{array}$ & - \\
\hline $\begin{array}{l}\text { Spergula arvensis subsp. } \\
\text { arvensis }\end{array}$ & 3 & I & $(\mathrm{r}-+)$ & $\begin{array}{l}\text { archeofit zadomowiony } \\
\text { settled archaeophyte }\end{array}$ & - \\
\hline Thlaspi arvense & 7 & I & $(\mathrm{r}-1.2)$ & $\begin{array}{l}\text { archeofit zadomowiony } \\
\text { settled archaeophyte }\end{array}$ & 6 \\
\hline Veronica polita & 1 & I & (r) & $\begin{array}{l}\text { archeofit zadomowiony ustępujący } \\
\text { settled archaeophyte receding }\end{array}$ & - \\
\hline Vicia angustifolia & 1 & I & (r) & $\begin{array}{l}\text { archeofit zadomowiony } \\
\text { settled archaeophyte }\end{array}$ & - \\
\hline Vicia hirsuta & 5 & I & $(\mathrm{r}-+)$ & $\begin{array}{l}\text { archeofit zadomowiony } \\
\text { settled archaeophyte }\end{array}$ & - \\
\hline Vicia tetrasperma & 3 & I & $(\mathrm{r}-1.2)$ & $\begin{array}{l}\text { archeofit zadomowiony } \\
\text { settled archaeophyt }\end{array}$ & 5 \\
\hline Viola arvensis & 33 & II & $(\mathrm{r}-+)$ & $\begin{array}{l}\text { archeofit zadomowiony } \\
\text { settled archaeophyte }\end{array}$ & 8,5 \\
\hline Galinsoga ciliata & 27 & II & $(r-3.3)$ & $\begin{array}{l}\text { kenofit inwazyjny } \\
\text { invasive kenophyte }\end{array}$ & 139,3 \\
\hline Galinsoga parviflora & 13 & I & $(+-3.4)$ & $\begin{array}{l}\text { kenofit inwazyjny } \\
\text { invasive kenophyte }\end{array}$ & 113,0 \\
\hline Oxalis fontana & 43 & III & $(r-3.4)$ & $\begin{array}{l}\text { kenofit inwazyjny } \\
\text { invasive kenophyte }\end{array}$ & 110,2 \\
\hline Veronica persica & 59 & IV & $(+-3.4)$ & $\begin{array}{l}\text { kenofit inwazyjny } \\
\text { invasive kenophyte }\end{array}$ & 511,9 \\
\hline \multicolumn{6}{|c|}{ Artemisietea vulgaris } \\
\hline Armoracia rusticana & 2 & I & (r) & $\begin{array}{l}\text { archeofit zadomowiony } \\
\text { settled archaeophyte }\end{array}$ & - \\
\hline \multicolumn{6}{|c|}{ Molinio-Arrhenatheretea } \\
\hline Chamomilla suaveolens & 2 & I & $(\mathrm{r}-+.2)$ & $\begin{array}{l}\text { kenofit zadomowiony } \\
\text { settled keophyte }\end{array}$ & 0,1 \\
\hline
\end{tabular}


Tabela 6. Charakterystyka antropofitów najczęściej występujących w uprawach kukurydzy na Pogórzu Cieszyńskim - cd. Table 6. Characteristics of anthropophytes most frequently found in maize crops in the Cieszyńskie Foothills - continued

\begin{tabular}{|c|c|c|c|c|c|}
\hline 1 & 2 & 3 & 4 & 5 & 6 \\
\hline \multicolumn{6}{|c|}{ Bez przynależności fitosocjologicznej - No phytosociologial affiliation } \\
\hline Sherardia arvensis & 22 & II & $(+-2.3)$ & $\begin{array}{c}\text { archeofit zadomowiony } \\
\text { settled archaeophyte }\end{array}$ & 136,5 \\
\hline Amaranthus retroflexus & 12 & I & $(\mathrm{r}-1.1)$ & $\begin{array}{l}\text { kenofit inwazyjny } \\
\text { invasive kenophyte }\end{array}$ & 17,6 \\
\hline Fumaria vaillantii & 3 & I & $(\mathrm{r}-+)$ & $\begin{array}{l}\text { archeofit ustępujący } \\
\text { receding archaeophyte }\end{array}$ & 0,2 \\
\hline Lolium multiflorum & 3 & I & $(+.2)$ & $\begin{array}{l}\text { kenofit inwazyjny } \\
\text { invasive kenophyte }\end{array}$ & 0,3 \\
\hline Abutilon theoprasti & 2 & I & $(1.2-2.3)$ & $\begin{array}{c}\text { archeofit zadomowiony } \\
\text { settled archaeophyte }\end{array}$ & 25,3 \\
\hline Robinia pseudoacacia & 2 & I & $(\mathrm{r}-+.2)$ & $\begin{array}{l}\text { kenofit inwazyjny } \\
\text { invasive kenophyte }\end{array}$ & 0,1 \\
\hline Senecio vulgaris & 2 & I & (r) & $\begin{array}{l}\text { archeofit zadomowiony } \\
\text { settled archaeophyte }\end{array}$ & - \\
\hline Juglans regia & 1 & I & (r) & $\begin{array}{l}\text { kenofit inwazyjny } \\
\text { invasive kenophyte }\end{array}$ & 0,1 \\
\hline
\end{tabular}

cheofity nawiązujące do Stellarietea mediae to gatunki zadomowione we florze Polski. Na liście gatunków chwastów występujących w uprawach kukurydzy znajdują się taksony zagrożone oraz te, których status zagrożenia trudno określić, ze względu na brak wystarczających informacji (Kaźmierczakowa i wsp. 2016). Należą do nich Aethusa cynapium subsp. agrestis (Wallr.) Dostál - blekot pospolity polny (DD - Data Deficient - takson, którego stopień zagrożenia nie może być określony z powodu braku wystarczających informacji) - stosunkowo częsty w uprawach, głównie zbóż i kukurydzy, w niektórych płatach pokrywał do 45\% powierzchni badanej; Euphorbia exigua L. - wilczomlecz drobny (NT - Near Threatened - bliski zagrożenia) - częsty, głównie w południowo-zachodniej części Pogórza Cieszyńskiego, na glebach z rumoszem wapiennym na powierzchni; Fumaria vaillantii Loisel - dymnica drobnokwiatowa (VU - Vulnerable - gatunek narażony) - bardzo rzadko, głównie w miejscach bez zastosowania herbicydów; Kickxia elatine (L.) Dumort - kiksja oszczepowata (VU) - bardzo często, głównie w południowo-zachodniej części Pogórza Cieszyńskiego, na glebach z rumoszem wapiennym na powierzchni, niektóre badane powierzchnie były pokryte w 40\%; Kickxia spuria (L.) Dumort - kiksja zgiętoostrogowa (CR - Critically Endangered - gatunek krytycznie zagrożony) - niezwykle rzadko, oprócz plantacji kukurydzy stwierdzono jej obecność w uprawie mieszanek zbóż jarych; Silene gallica L. - lepnica francuska (EN - Endangered - gatunek zagrożony) - bardzo rzadki, w stosunku do lat 2005-2008 stwierdzono zmniejszenie liczby wystąpień; Veronica polita Fr. - przetacznik lśniący (DD).
Na zmiany w składzie zbiorowisk roślinności towarzyszącej roślinom uprawnym, w tym zanikanie gatunków dotąd powszechnie występujących w warunkach Polski wskazują między innymi Kącki i wsp. (2003) oraz Kącki i Czarniecka (2011).

Na plantacjach kukurydzy obecne były również gatunki archeofitów inwazyjnych, do których należą między innymi Avena fatua, Echinochloa crus-galli, Setaria pumila i Setaria viridis (Tokarska-Guzik i wsp. 2012). Szczególną uwagę zwraca obecność E. crus-galli, której próg szkodliwości w uprawie kukurydzy wynosi 6 szt. $/ \mathrm{m}^{2}$ (Bereś i Mrówczyński 2016). W analizowanych płatach upraw kukurydzy chwastnica jednostronna pokrywała maksymalnie $50 \%$ badanych powierzchni. Taki poziom zachwaszczenia może skutkować obniżeniem efektu ekonomicznego nawet do 80\% (Paczyńska 2016). Podobne zależności występują w przypadku gatunków włośnic (S. pumila, S. viridis) oraz żółtlic (Galinsoga ciliata, Galinsoga parviflora). Nie bez znaczenia jest fakt, iż masowe pojawienie się gatunków chwastów inwazyjnych wzbogaca pulę nasion zalegających w glebie, np. w przypadku E. crus-galli roślina produkuje do 5000 ziarniaków (Paczyńska 2016), co rzutuje na zachwaszczenie upraw w następnych latach.

\section{Wnioski / Conclusions}

1. W uprawach kukurydzy na Pogórzu Cieszyńskim stwierdzono znaczne bogactwo występujących w uprawie kukurydzy gatunków chwastów. 
2. Gatunkami antropofitów ograniczającymi plonowanie kukurydzy na Pogórzu Cieszyńskim są gatunki archeofitów - E. crus-galli, S. pumila, A. fatua, a w ostatnim czasie $A$. theophrasti oraz kenofit - G. parviflora.
3. Wśród chwastów odnotowano obecność gatunków zagrożonych i ustępujących z upraw rolniczych (np. A. cynapium subsp. agrestis, $K$. elatine).

\section{Literatura / References}

Bereś P.K., Mrówczyński M. 2016. Metodyka integrowanej ochrony i produkcji kukurydzy dla doradców. Instytut Ochrony Roślin - Państwowy Instytut Badawczy, Poznań, 261 ss. ISBN 978-83-64655-23-4.

Blecharczyk A., Małecka I., Skrzypczak G. 2004. Wpływ uproszczonej uprawy roli na plonowanie i zachwaszczenie kukurydzy oraz na właściwości gleby. Acta Scientiarum Polonorum Agricultura 3 (1): 157-163.

Celka Z. 2004. Atlas rozmieszczenia roślin naczyniowych na grodziskach Wielkopolski. Prace Zakładu Taksonomii Roślin Uniwersytetu im. Adama Mickiewicza w Poznaniu. Wydawnictwo Naukowe, Bogucki, Poznań 13: 7-448.

Chmiel J. 2006. Zróżnicowanie przestrzenne flory jako podstawa ochrony przyrody w krajobrazie rolniczym. Prace Zakładu Taksonomii Roślin Uniwersytetu im. Adama Mickiewicza w Poznaniu. Wydawnictwo Naukowe, Bogucki, Poznań 14: 4-250.

Dubas A., Sulewska H., Menzel L. 2002. Zachwaszczenie kukurydzy uprawianej w monokulturze przy uproszczeniach w uprawie roli. [Weed infestation of maize grown in monoculture and no-tillage system]. Progress in Plant Protection/Postępy w Ochronie Roślin 42 (2): 604-606.

Fried G., Norton L.R., Reboud X. 2008. Environmental and management factors determining weed species composition and diversity in France. Agriculture, Ecosystems and Environment 128 (1-2): 68-76. DOI: 10.1016/j.agee.2008.05.003

Głowacka A. 2007. Wpływ współrzędnej uprawy pasowej na zachwaszczenie kukurydzy pastewnej. [Effect of strip intercropping system on weed infestation in maize]. Acta Agrophysica 10 (3): 573-582.

Gołębiowska H. 2006. Wpływ wieloletniej uprawy kukurydzy na ziarno na występowanie chwastów. Pamiętnik Puławski 142: $127-136$.

Gołębiowska H. 2007. Bioróżnorodność zachwaszczenia w kukurydzy oraz chemiczne sposoby jego zwalczania. [Biodiversity of weed communities in maize and chemical systems of weed control]. Progress in Plant Protection/Postępy w Ochronie Roślin 47 (3): 96-107.

Gołębiowska H., Snopczyński T., Domaradzki K., Rola H. 2015. Zmiany w zachwaszczeniu kukurydzy w południowo-zachodnim rejonie Polski w latach 1963-2013. [Changes in weed infestation in corn crops in southwestern region of Poland in 1963-2013 years]. Progress in Plant Protection 55 (3): 327-339.

Imoloame E.O., Omolaiye J.O. 2017. Weed infestation, growth and yield of maize (Zea mays L.) as influenced by periods of weed interference. Advances in Crop Science and Technology 5 (2): 267. DOI: 10.4172/2329-8863.1000267

Kaźmierczakowa R. (red.), Bloch-Orłowska J., Celka Z., Cwener A., Dajdok Z., Michalska-Hejduk D., Pawlikowski P., Szczęśniak E., Ziarnek K. 2016. Polska czerwona lista paprotników i roślin kwiatowych. Instytut Ochrony Przyrody Polskiej Akademii Nauk, Kraków, 44 ss.

Kącki Z., Czarniecka M. 2011. Kickxia elatine (Scrophulariaceae) na Dolnym Śląsku. Występowanie i zagrożenia. Acta Botanica Silesiaca, Supplementum 1: 147-149.

Kącki Z., Dajdok Z., Szczęśniak E. 2003. Czerwona lista roślin naczyniowych Dolnego Śląska. W: Zagrożone gatunki flory naczyniowej Dolnego Śląska (Z. Kącki, red.). Instytut Biologii Roślin, Uniwersytet Wrocławski, PTPP „Pro Natura”: 9-65.

Kierzek R., Miklaszewska K., Krawczyk R., Matysiak K. 2011. Wpływ terminu nalistnego stosowania w kukurydzy mieszanin herbicydów na ich efektywność chwastobójczą. [Effect of the foliage application date of herbicide mixtures on weed control in maize]. Progress in Plant Protection/Postępy w Ochronie Roślin 51 (4): 1836-1841.

Lazar J. 1962. Gleby województwa katowickiego. Możliwości ich ulepszania i inne czynniki produkcji roślinnej (klimat, budowa geologiczna itp.) oraz ogólne podstawy gospodarki rolnej i leśnej i rejonizacji produkcji rolnej i leśnej. Państwowe Wydawnictwo Rolnicze i Leśne, Warszawa, 304 ss.

Majchrzak L., Skrzypczak G. 2007. Wpływ sposobu przygotowania gleby do siewu i rodzaju pozostawionej biomasy na zachwaszczenie kukurydzy. [The influence of tillage system and crop residue on weeds infestation in maize]. Progress in Plant Protection/Postępy w Ochronie Roślin 47 (3): 191-198.

Majchrzak L., Skrzypczak G., Pudełko J. 2003. Zmiany w zachwaszczeniu kukurydzy w zależności od sposobu uprawy. [Weed population variability in maize influenced by tillage system]. Zeszyty Problemowe Postępów Nauk Rolniczych 490: 153-161.

Matuszkiewicz W. 2001. Przewodnik do oznaczania zbiorowisk roślinnych Polski. Państwowe Wydawnictwo Naukowe, Warszawa, $537 \mathrm{ss}$.

Mirek Z., Piękoś-Mirkowa H., Zając A., Zając M. 2002. Flowering Plants and Pteridiophytes of Poland. A Checklist. Series: Biodiversity of Poland, Vol. 1. [Krytyczna lista roślin kwiatowych i paprotników Polski]. Instytut Botaniki im. W. Szafera, Polska Akademia Nauk, Kraków, 442 ss. ISBN 83-85444-83-1.

Paczyńska D. 2016. Chwasty inwazyjne w uprawach. Małopolski Ośrodek Doradztwa Rolniczego, Karniowice, 26 ss.

Pawłowski B. 1972. Skład i budowa zbiorowisk roślinnych oraz metody ich badania. W: Szata roślinna Polski (W. Szafer, K. Zarzycki, red.). Państwowe Wydawnictwo Naukowe, Warszawa: 237-269.

Piskier T., Sekutowski T.R. 2013. Wpływ uproszczeń w uprawie roli na liczebność oraz rozmieszczenie nasion chwastów w glebie. [Effect of simplified tillage on the number and distribution of weed seeds in soil]. Journal of Research and Applications in Agricultural Engineering 58 (4): 109-117.

Pudełko J., Skrzypczak G., Maciejewski T. 2006. Zachwaszczenie kukurydzy uprawianej po ziemniakach i zbożach. [Weed populations resulting from forecrop in maize]. Progress in Plant Protection/Postępy w Ochronie Roślin 46 (2): 210-214.

Rola H., Sekutowski T., Gierczyk T. 2005. Wpływ systemów uprawy kukurydzy w monokulturze na stan zachwaszczenia łanu. Pamiętnik Puławski 140: 245-249.

Rychcik B. 2006. Wpływ herbicydów i następstwa roślin na zachwaszczenie kukurydzy (Zea mays L.). [Effect of herbicides and crop sequence on weed infestation of maize (Zea mays L.)]. Progress in Plant Protection/Postępy w Ochronie Roślin 46 (2): $170-173$. 
Rychcik B., Tyburski J., Zawiślak K. 2003. Efektywność płodozmianu i herbicydów w ograniczaniu zachwaszczenia kukurydzy. [Efect of crop rotation and herbicides in reduction of maize weed infestation]. Zeszyty Problemowe Postępów Nauk Rolniczych 490: $203-209$.

Sobiech Ł., Idziak R., Skrzypczak G., Szulc P., Grzanka M. 2018. Bioróżnorodność zachwaszczenia kukurydzy na glebie płowej. [Biodiversity of weed flora in maize on lessive soil]. Progress in Plant Protection 58 (4): 282-287.

Sowiński J. 2006. Zmiany stopnia zachwaszczenia kukurydzy w zależności od sposobu pielęgnacji. [Changes of weed density in maize depending on weed control methods]. Progress in Plant Protection/Postępy w Ochronie Roślin 46 (2): 142-144.

Szulc P., Dubas A. 2008. Zachwaszczenie kukurydzy uprawianej w wieloletniej monokulturze. [Weed occurrence in maize (Zea mays L.) growing in long-lasting monoculture]. Progress in Plant Protection/Postępy w Ochronie Roślin 48 (1): 317-323.

Tokarska-Guzik B., Dajok Z., Zając M., Zając A., Urbisz A., Danielewicz W., Hołdyński C. 2012. Rośliny obcego pochodzenia w Polsce ze szczególnym uwzględnieniem gatunków inwazyjnych. Generalna Dyrekcja Ochrony Środowiska, Warszawa, 197 ss. ISBN 978-83-62940-34-9.

Waligóra H., Szulc P., Skrzypczak W. 2008. Skuteczność chemicznego zwalczania chwastów w kukurydzy cukrowej bez użycia triazyn. [Effectiveness of chemical weed control in sugar maize cultivation without triazyne]. Acta Scientiarum Polonorum, Agricultura 7 (1): $111-118$.

Wanic M., Jastrzębska M., Kostrzewska M.K., Nowicki J. 2005. Analiza zbiorowisk chwastów za pomocą wybranych wskaźników biologicznych. [Analysis of weeds communities using selected biological indicators]. Acta Agrobotanica 58 (1): $227-242$.

Wesołowski M., Woźniak A. 1998. Plonowanie i zachwaszczenie kukurydzy uprawianej w zmianowaniu dowolnym i monokulturze na glebie wytworzonej z piasku. Fragmenta Agronomica 15 (3): 70-79.

Woźniak A., Soroka M. 2015. Syntaksonomiczna ocena zbiorowisk chwastów w zasiewach żyta (Secale cereale L.) na polach ukraińskiego Roztocza. [Syntaxonomic evaluation of weed communities in rye in the Ukrainian Roztocze]. Fragmenta Agronomica 32 (2): 97-110. 